\title{
FEKUNDITAS DAN TINGKAT KEMATANGAN GONAD RAJUNGAN (PortunUS pelagicus) BETINA MENGERAMI TELUR DI TELUK LASONGKO, SULAWESI TENGGARA
}

\section{FECUNDITY AND GONAD MATURITY STAGES OF OVIGEROUS FEMALE BLUE SWIMMING CRAB (Portunus pelagicus) IN LASONGKO BAY, SOUTHEAST SULAWESI}

\author{
Abdul Hamid ${ }^{1,2}$, Yusli Wardiatno ${ }^{3}$, Djamar T.F.Lumban Batu ${ }^{3}$, Etty Riani $^{3}$ \\ 1)Pascasarjana Institut Pertanian Bogor, Bogor \\ ${ }^{2}$ Fakultas Perikanan dan Ilmu Kelautan Universitas Halu Oleo, Kendari \\ ${ }^{3}$ Departemen Manajemen Sumber Daya Perairan, Fakultas Perikanan dan Ilmu Kelautan, Institut Pertanian Bogor, Bogor \\ Teregistrasi I tanggal: 21 Mei 2014; Diterima setelah perbaikan tanggal: 25 Maret 2015; \\ Disetujui terbit tanggal: 02 April 2015 \\ e-mail: ywardiatno@hotmail.com
}

\begin{abstract}
ABSTRAK
Kajian kematangan gonad pada rajungan betina mengerami telur dan fekunditas berdasarkan warna telur masih terbatas. Penelitian ini menganalisis fekunditas dan tingkat kematangan gonad rajungan betina mengerami telur di Teluk Lasongko, dilakukan dari bulan April 2013 sampai Maret 2014. Fekunditas rajungan dianalisis berdasarkan kelas ukuran tubuh dan warna rajungan betina mengerami telur. Tingkat kematangan gonad ditentukan berdasarkan perubahan warna dan morfologi gonad. Fekunditas rajungan berkisar 69.747-2.078.874 butir dengan lebar karapas 86,6-162,3 mm. Fekunditas rajungan bervariasi terhadap ukuran tubuh dan warna rajungan mengerami telur, serta berkorelasi dengan ukuran tubuh dan berat telur. Rajungan betina mengerami telur ditemukan dari TKG I sampai IV. Fekunditas rajungan di perairan ini tergolong sedang sampai tinggi, rajungan betina mengerami telur berwarna kuning dan orange didominasi belum matang gonad sedangkan berwarna coklat dan abu-abu gelap didominasi matang gonad.
\end{abstract}

KATA KUNCI: Rajungan, fekunditas, kematangan gonad, Teluk Lasongko

\section{ABSTRACT}

Gonad maturity studied on ovigerous female and fecundity blue simming crabs based on the color of the egg was still limited. This study analyzed which fecundity and gonad maturity stages of ovigerous female blue swimming crab in Lasongko Bay, conducted from April 2013 to March 2014. The fecundity of crabs analyzed based on class of size and color of the ovigerous female. Gonad maturity stages determined based on of changes of color and morphology of the gonads. Fecundity and carapace width were found from 69,747 to 2,078,874 grains with width caparace 86.6 to $162.3 \mathrm{~mm}$. Crab fecundity varies with body size and color of ovigerous female, as well as correlation with body size and egg weight. The gonad maturity stages of ovigerous female crab were found from gonad maturity stage I to stage IV. Fecundity of crabs in these waters classified as moderate to high, and ovigerous female crab yellow and orange color are gonad immature predominantly, while brown and dark gray color are gonad mature.

KEYWORDS: Blue swimming crab, fecundity, gonad maturity, Lasongko Bay

\section{PENDAHULUAN}

Teluk Lasongko merupakan daerah penangkapan rajungan di Sulawesi Tenggara dan dilakukan penangkapan secara intensif sejak awal tahun 2000-an, karena tingginya permintaan rajungan sebagai bahan baku pengolahan daging rajungan di kawasan ini (Hamid, 2011). Penangkapan rajungan yang intensif tersebut telah berdampak pada hasil tangkapan nelayan semakin menurun dan ukuran rajungan yang tertangkap semakin kecil (Hamid, 2011), namun dampaknya terhadap aspek biologi reproduksi rajungan belum dikaji.
Fekunditas dan tingkat kematangan gonad (TKG) merupakan aspek penting dalam biologi reproduksi rajungan, Portunus pelagicus (Arshad et al., 2006, Ikhwanuddin et al., 2012), serta fekunditas rajungan dikategorikan sebagai batch fekunditas, yaitu jumlah telur yang dikeluarkan secara bertahap (de Lestang et al., 2003). Rajungan betina pada setiap musim pemijahan dapat mengeluarkan telur satu sampai tiga tahap tergantung pada ukuran tubuhnya (Sumpton et al., 1994, de Lestang et al., 2003, Johnson et al., 2010). Fekunditas rajungan dilaporkan bervariasi antar lokasi geografi, ukuran dan antar individu pada kelas ukuran tubuh yang sama (Batoy 
et al., 1987, Shields \& Wood, 1993, Sukumaran 1995, Johnson et al., 2010, Jazayeri et al., 2011, Ikhwanuddin et al., 2012, Josileen, 2013, Safaie et al., 2013). Selanjutnya disebutkan bahwa adanya varaisi fekunditas tersebut kerena perbedaan ukuran, umur, dan struktur populasi rajungan, ketersedian makanan, parasit dan kondisi habitat antar lokasi perairan.

Data fekunditas dan TKG berguna untuk memahami biologi dan dinamika populasi rajungan (Arshad et al., 2006) dan mengevaluasi penangkapan rajungan (Johnson et al., 2010). Kajian TKG rajungan selama ini masih terfokus pada rajungan betina belum mengerami telur sedangkan pada rajungan betina mengerami telur masih terbatas, diantaranya Pillay \& Nair, (1971) dan Sumpton et al. (1994). Kedua penelitian tersebut baru mengkaji TKG dan IKG rajungan betina mengerami telur secara temporal sedangkan berdasarkan perubahan warna telur belum dikaji, dan penelitian fekunditas rajungan berdasarkan perubahan warna telur baru dilakukan Safaie et al. (2013). Oleh karena itu, penelitian ini dengan tujuan menganalisis fekunditas dan TKG rajungan betina mengerami telur berdasarkan perubahan warna telur di Teluk Lasongko.

\section{BAHANDANMETODE}

Penelitian ini dilaksanakan dari bulan April 2013 sampai bulan Maret 2014 di Teluk Lasongko, Sulawesi Tenggara yang terletak pada posisi $05^{\circ} 15^{\prime}-05^{\circ} 27^{\prime}$ LS dan $122^{\circ} 27^{\prime}$ $122^{\circ} 33^{\prime}$ BT (Gambar 1). Pengambilan contoh rajungan betina mengerami telur dilakukan setiap bulan dengan gillnet dasar, dan juga dari hasil tangkapan nelayan yang menangkap di sekitar lokasi penelitian (Gambar 1). Rajungan yang diperoleh pada setiap kali sampling disimpan dalam freezer, dan saat dibawa ke laboratorium digunakan cold box berisi es.

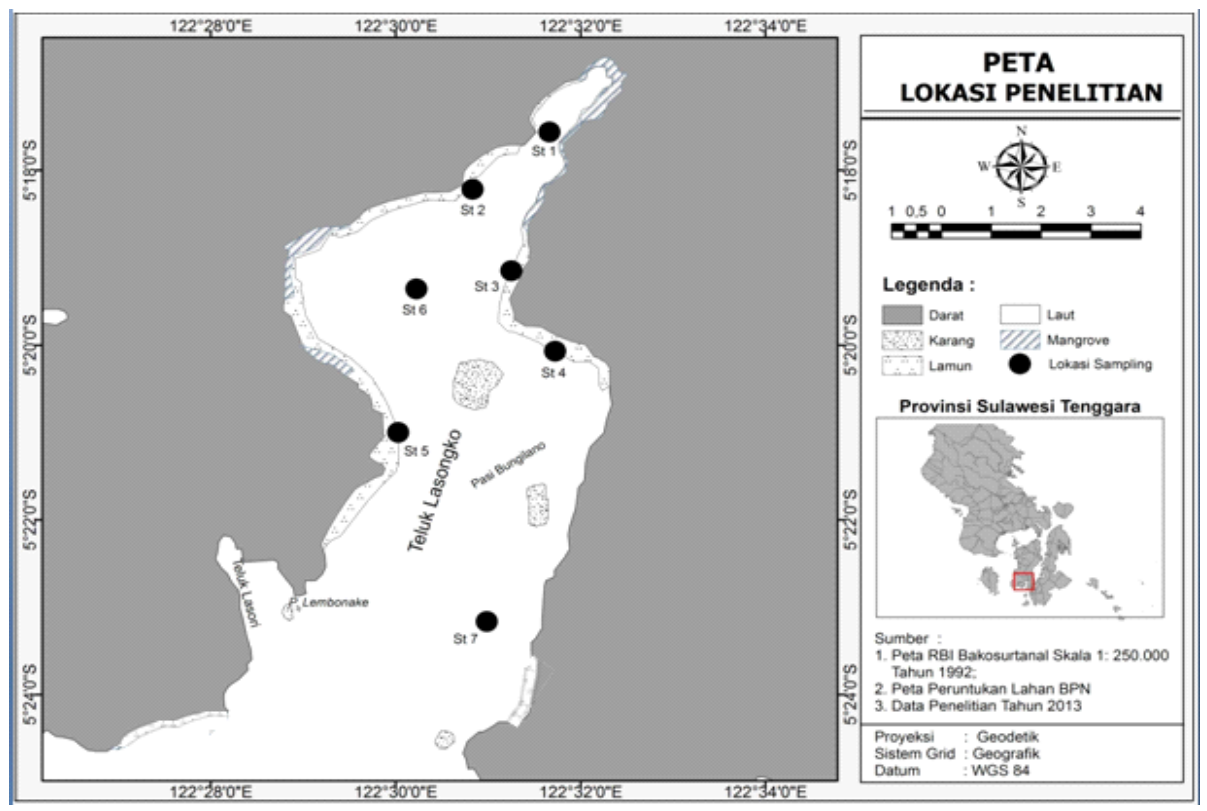

Gambar 1. Peta lokasi penelitian dan pengambilan contoh di Teluk Lasongko.

Figure 1. Map of the study and sampling site in Lasongko Bay.

Dalam analisis fekunditas digunakan 113 ekor rajungan betina mengerami telur yang terdiri dari 49 ekor warna kuning, 45 warna orange dan 19 ekor warna coklat muda (Gambar 2). Berat tubuh dan berat telur setiap rajungan tersebut timbangan dengan digital berketelitian $0,01 \mathrm{~g}$ dan diukur lebar karapasnya dengan kaliper berketelitian $0,05 \mathrm{~mm}$. Contoh telur dengan berat 0,20 $0,40 \mathrm{~g}$ dihitung jumlahnya di bawah mikroskop binokuler, kemudian fekunditas rajungan ditentukan berdasarkan persamaan (Jazayeri et al., 2011) seperti berikut :

$$
\begin{aligned}
F & =n \frac{G}{g}
\end{aligned}
$$




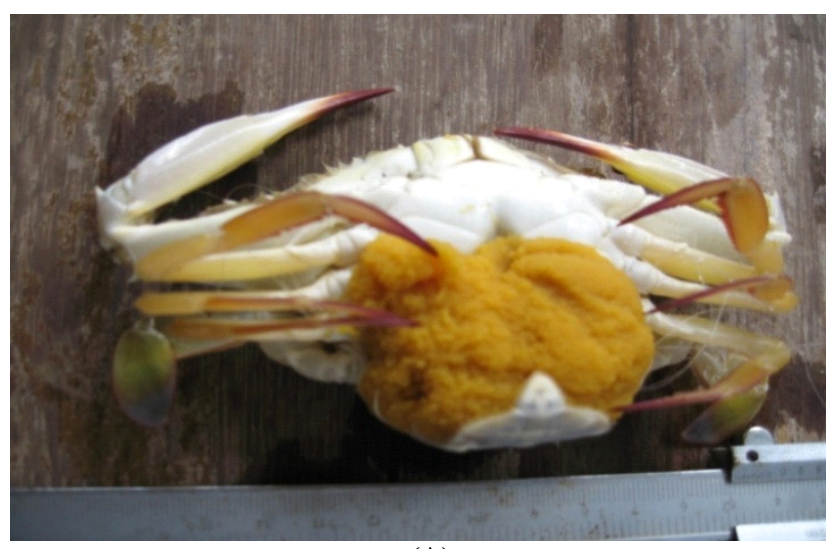

(A)

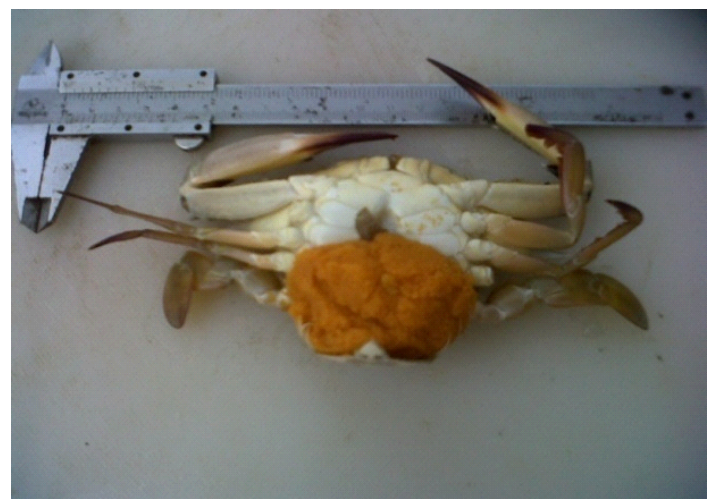

(B)

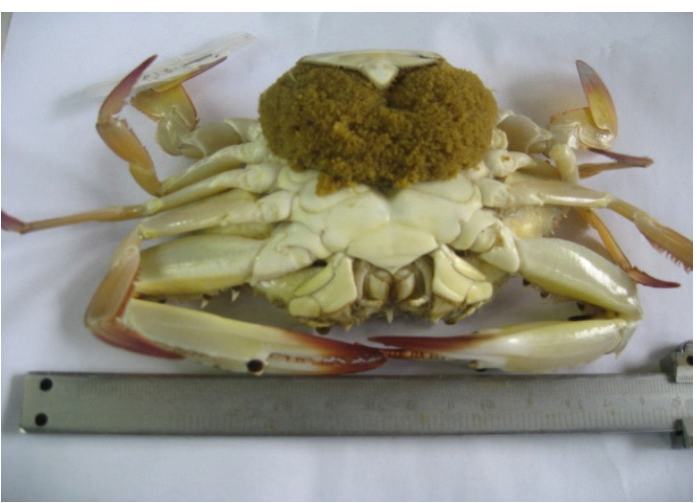

(C)

Gambar 2. Rajungan betina mengerami telur berwarna kuning (A), oranye (B) dan coklat muda (C).

Figure 2. Ovigerous female blue swimming crab of yellow (A), orange (B) and brown (C) colors.

Fekunditas rajungan dikelompokkan berdasarkan kelas ukuran tubuh dan warna telur, serta untuk mengetahui variasi fekunditas pada setiap kelas ukuran dan warna rajungan betina mengerami telur dihitung koefisien variasinya dengan persamaan berikut:

Koefisien variasi $=\frac{\text { Standar deviasi fekunditas (butir) }}{\text { Rataan fekunditas (butir) }} \times 100 \% \ldots$

Indeks masa telur pada setiap kelas ukuran dan warna telur ditentukan berdasarkan (Josileen, 2013) dengan persamaan :

Indeks masa telur $=\frac{\text { Rataan berat telur }(\mathrm{g})}{\text { Rataan berat rajungan }(\mathrm{g})} X 100 \%$

Hubungan lebar karapas, berat tubuh dan berat telur dengan fekunditas dianalisis dengan regresi linear (Johnson et al., 2010, Ikhwanuddin et al., 2012, Safaie et al., 2013) dengan persamaan berikut :

$\mathrm{F}=\mathrm{a}+\mathrm{bX}$

$\mathrm{F}=$ fekunditas rajungan (butir), $\mathrm{X}=$ lebar karapas (mm) atau berat tubuh $(\mathrm{g})$.
Jumlah rajungan betina mengerami telur yang digunakan dalam analisis TKG sebanyak 168 ekor, terdiri dari 57 ekor warna kuning, 48 warna orange, 31 warna coklat dan 32 ekor warna abu-abu gelap. TKG rajungan betina mengerami telur dibagi dalam empat tingkat yang didasarkan pada (de Lestang et al., 2003, Kamrani et al., 2010, Ikhwanuddin et al., 2012). Ciri-ciri setiap tingkat, yaitu (1) TKG I ovarium masih kecil dan transparan, (2) TKG II ovarium bertambah besar, namun belum menempati daerah hepatik dan berwarna krem atau kuning muda, (3) TKG III ovarium semakim besar dan menempati daerah hepatik sekitar $1 / 3$ sampai $1 / 4$, berwarna kuning tua atau gading, dan (4) TKG IV ovarium menempati sebagian besar daerah hepatik, adanya lobulus, ovarium berwarna orange atau orange kemerahan. Rajungan betina mengerami telur yang gonadnya belum berkembang dikategorikan TKG $\operatorname{nol}(0)$.

Indeks kematangan gonad (IKG) rajungan betina mengerami telur setiap TKG ditentukan berdasarkan Kamrani et al. (2010) dengan persamaan berikut :

$I K G=\frac{\text { Berat gonad }(\mathrm{g})}{\text { Berat tubuh }(\mathrm{g})} X 100 \%$ 


\section{HASIL DAN BAHASAN HASIL}

\section{Fekunditas Berdasarkan Kelas Ukuran Tubuh}

Fekunditas rajungan tertangkap di Teluk Lasongko berkisar 69.747-2.078.874 butir dengan lebar karapas 86,6$162,3 \mathrm{~mm}$ dan rataan fekunditas berdasarkan kelas ukuran tertera pada Tabel 1. Variasi fekunditas rajungan tertinggi ditemukan pada kelas ukuran 86,6 - 96,6 mm (71.49\%), karena jumlah contoh yang dianalisis sedikit ( 2 ekor), sedangkan variasi terendah ditemukan pada kelas ukuran
126,7-136,6 mm (23.13\%). Rajungan betina mengerami telur pada kelas ukuran146,7-156,6 mm tidak ditemukan pada penelitian ini. Indeks masa telur ditemukan pada penelitian ini cenderung semakin besar dengan meningkatnya ukuran tubuh rajungan betina mengerami telur.

Hasil analisis regresi menunjukkan hubungan fekunditas dengan lebar karapas, berat tubuh dan berat telur sangat nyata $(\mathrm{P}<0,01)$, berkorelasi kuat dan positif, demikian juga antara berat tubuh dan berat telur rajungan (Tabel 2).

Tabel 1. Rataan berat tubuh, berat telur, fekunditas dan indeks masa telur berdasarkan kelas ukuran tubuh rajungan betina mengerami telur

Table 1. Mean of body weight, egg weight, fecundity and egg mass index based of body size class ovigerous female blue swimming carb

\begin{tabular}{|c|c|c|c|c|c|c|}
\hline $\begin{array}{l}\text { Kelas ukuran/ } \\
\text { Size class (mm) }\end{array}$ & $\begin{array}{c}\text { Jumlah } \\
\text { contoh/ } \\
\text { Sampling } \\
\text { total }\end{array}$ & $\begin{array}{c}\text { Berat tubuh/ } \\
\text { Body weight } \\
\text { (g) }\end{array}$ & $\begin{array}{c}\text { Berat telur/ } \\
\text { Egg weight } \\
\text { (g) }\end{array}$ & $\begin{array}{c}\text { Fekunditas/ } \\
\text { Fecundity } \\
\text { (butir/grain) }\end{array}$ & $\begin{array}{c}\text { Koefisien } \\
\text { variasi/ } \\
\text { Coefisient } \\
\text { Variation } \\
(\%) \\
\end{array}$ & $\begin{array}{c}\text { Indeks masa } \\
\text { telur/ } \\
\text { Gonad index }\end{array}$ \\
\hline $86,6-96,6$ & 2 & $89,09 \pm 46,34$ & $13,76 \pm 9,45$ & $469.666 \pm 237.433$ & 71,49 & 15,45 \\
\hline $96,7-106,6$ & 17 & $78,20 \pm 7,97$ & $12,25 \pm 3,21$ & $430.416 \pm 136.317$ & 29,91 & 15,66 \\
\hline $106,7-116,6$ & 33 & $103,31 \pm 11,39$ & $16,30 \pm 3,53$ & $599.717 \pm 151.270$ & 26,01 & 15,78 \\
\hline $116,7-126,6$ & 34 & $128,10+12,37$ & $19,90 \pm 4,11$ & $694.927 \pm 185.532$ & 26,30 & 15,53 \\
\hline $126,7-136,6$ & 17 & $166,77 \pm 20,35$ & $27,09 \pm 4.36$ & $963.135 \pm 222.733$ & 23,13 & 16,24 \\
\hline $136,7-146,6$ & 10 & $194,98 \pm 22,03$ & $27,59 \pm 7,55$ & $1.147 .353 \pm 492.515$ & 42,93 & 14,15 \\
\hline $156,7-166,6$ & 1 & 314,22 & 54,46 & 2.078 .874 & - & 17,33 \\
\hline
\end{tabular}

Tabel2. Hubungan lebar karapas, berat tubuh dan berat telur dengan fekunditas untuk total contoh rajungan betina mengerami telur $(\mathrm{n}=113)$

Table 2. Carapace width, body weight and egg weight with fecundity relationships for total sample of ovigerous female blue swimming carb $(n=113)$

\begin{tabular}{lllccc}
\hline No. & \multicolumn{1}{c}{ Hubungan/Relationship } & Persamaan/Equation & $\mathbf{R}$ & $\mathbf{R}^{\mathbf{2}}$ & Taraf nyata \\
\hline 1. & Lebar karapas - fekunditas & $\mathrm{F}=19.268 \mathrm{Lk}-2 \mathrm{E}+06$ & 0,747 & 0,563 & $\mathrm{P}<0,01$ \\
2. & Berat total tubuh - fekunditas & $\mathrm{F}=6.224 \mathrm{Bt}-53530$ & 0,836 & 0,699 & $\mathrm{P}<0,01$ \\
3. & Berat telur - fekunditas & $\mathrm{F}=35.433 \mathrm{Be}+21.145$ & 0,915 & 0,837 & $\mathrm{P}<0,01$ \\
4. & Berat total tubuh - berat telur & $\mathrm{Be}=0,0162 \mathrm{Bt}-0,461$ & 0,845 & 0,714 & $\mathrm{P}<0,01$ \\
\hline
\end{tabular}

\section{Fekunditas Berdasarkan Warna Telur}

Rataan fekunditas rajungan berdasarkan warna telur berkisar 700.698-733.794 butir dengan koefisien variasi berkisar $23,98-49,00 \%$. Rataan berat tubuh, berat telur, fekunditas dan indeks masa telur rajungan betina mengerami telur berwarna coklat muda lebih besar dari pada warna kuning dan orange, namum rataan fekunditas tertinggi ditemukan pada rajungan betina mengerami telur berwarna coklat muda (Tabel 3). Indeks masa telur rajungan betina mengerami telur cenderung meningkat dari warna kuning ke warna coklat muda.

Tabel 3. Rataan ukuran tubuh, berat telur, fekunditas dan indeks masa telur berdasarkan warna rajungan betina mengerami telur ( $\mathrm{KV}=$ koefisien variasi fekunditas)

Table 3. Mean of body size, egg weight, fecundity and egg mass index based of color ovigerous female blue swimming carb ( $K V=$ variation coefisient of fecundity)

\begin{tabular}{|c|c|c|c|c|c|c|c|}
\hline $\begin{array}{c}\text { Warna } \\
\text { telur/Egg } \\
\text { colour }\end{array}$ & $\begin{array}{l}\text { Jumlah } \\
\text { contoh/ } \\
\text { Sum of } \\
\text { Sample }\end{array}$ & $\begin{array}{c}\text { Lebar } \\
\text { karapas/ } \\
\text { Carapace } \\
\text { width }(\mathrm{mm})\end{array}$ & $\begin{array}{l}\text { Berat tubuh/ } \\
\text { Individual } \\
\text { weight } \\
\text { (g) }\end{array}$ & $\begin{array}{l}\text { Berat telur/ } \\
\text { Weight of } \\
\text { egg } \\
\text { (g) }\end{array}$ & $\begin{array}{l}\text { Fekundita/ } \\
\text { Fecundity } \\
\text { (telur/egg) }\end{array}$ & $\begin{array}{l}\text { KV } \\
(\%)\end{array}$ & $\begin{array}{c}\text { Indeks } \\
\text { masa } \\
\text { telur/Gonad } \\
\text { index } \\
\end{array}$ \\
\hline Kuning & 49 & $117,2 \pm 10,1$ & $124,08 \pm 34,47$ & $19,51 \pm 6,22$ & 700698 & 49,00 & 15,72 \\
\hline Orange & 45 & $120,0 \pm 9,0$ & $132,47 \pm 33,53$ & $19,91 \pm 7,52$ & 732186 & 47,40 & 15,03 \\
\hline Coklat muda & 19 & $117,3 \pm 5,9$ & $114,30 \pm 20,90$ & $20,85 \pm 4,34$ & 733794 & 23,98 & 18,24 \\
\hline
\end{tabular}


Tingkat Kematangan Gonad dan Keberadaan Rajungan Mengerami Telur

Hasil analisis TKG menunjukkan bahwa persentase TKG III dan IV (matang gonad) banyak ditemukan pada rajungan betina mengerami telur berwarna coklat dan abuabu gelap, masing-masing 48,39\% dan 43,76\%, sedangkan berwarna kuning dan orange didominasi oleh TKG I dan II (belum matang gonad), masing-masing dengan persentase $63.46 \%$ dan $55.91 \%$ (Tabel 4). Persentase rajungan betina mengerami telur dengan gonad belum berkembang (TKG 0) menurun dari warna orange ke warna abu-abu gelap. IKG rajungan betina mengerani telur warna kuning dan orange meningkat dari TKG I sampai TKG IV, sedangkan pada warna coklat dan abu-abu gelap hanya sampai TKG III meningkat, dan IKG rajungan betina mengerami telur pada TKG IV menurun.

Rajungan betina mengerami telur di Teluk Lasongko ditemukan setiap bulan selama penelitian dengan persentase terhadap total jumlah rajungan betina tertangkap setiap bulan berkisar 4,00\% - 35,71\%. Rajungan betina mengerami telur banyak tertangkap pada bulan November dan terendah pada bulan September (Gambar 3).

Tabel 4. Tingkat kematangan gonad, ukuran tubuh dan indeks kematangan gonad berdasarkan warna rajungan betina mengerami telur

Table 4. Gonad maturity stages, body size and gonad somato index based of color ovigerous female blue swimming carb

\begin{tabular}{|c|c|c|c|c|c|c|}
\hline $\begin{array}{l}\text { Warna telur/ } \\
\text { Egg colour }\end{array}$ & $\begin{array}{c}\text { TKG/ } \\
\text { TKG }\end{array}$ & $\begin{array}{l}\text { ¿contoh/ } \\
\text { Sampling }\end{array}$ & $\begin{array}{c}\text { Persentase/ } \\
\text { Percentage }(\%)\end{array}$ & $\begin{array}{c}\text { Lebar karapas/ } \\
\text { Carapace width } \\
(\mathrm{mm})\end{array}$ & $\begin{array}{c}\text { Berat tubuh/ } \\
\text { Individual Weight } \\
\text { (g) }\end{array}$ & $\begin{array}{l}\text { IKG/ } \\
I K G\end{array}$ \\
\hline \multirow[t]{5}{*}{ A. Kuning } & 0 & 11 & 21,15 & $117,2 \pm 9,4$ & $111,13 \pm 28,33$ & \\
\hline & I & 13 & 25,00 & $113,7 \pm 7,7$ & $117,18 \pm 23,03$ & $0,41 \pm 0,20$ \\
\hline & II & 20 & 38,46 & $115,1 \pm 8,8$ & $118,71 \pm 28,15$ & $1,23 \pm 0,51$ \\
\hline & III & 7 & 13,46 & $128,8 \pm 9,7$ & $175.45 \pm 39.29$ & $1,65 \pm 0,49$ \\
\hline & IV & 1 & 1,92 & 116,1 & 123.53 & $2, \overline{79}$ \\
\hline \multirow[t]{5}{*}{ B. Orange } & 0 & 13 & 27,08 & $116,6 \pm 10,1$ & $125,32 \pm 31,05$ & \\
\hline & I & 16 & 33,33 & $114,3 \pm 12,1$ & $110,24 \pm 34,43$ & $0,45 \pm 0,17$ \\
\hline & II & 12 & 25,00 & $124,3 \pm 8,0$ & $150,39 \pm 41,29$ & $0,86 \pm 0,25$ \\
\hline & III & 5 & 10,42 & $125,6 \pm 4,2$ & $141,54 \pm 14,23$ & $1,36 \pm 0,24$ \\
\hline & IV & 2 & 4,17 & $128,4 \pm 1,1$ & $159,83 \pm 1,36$ & $1,86 \pm 0,23$ \\
\hline \multirow[t]{5}{*}{ C. Coklat } & 0 & 7 & 22,58 & $113,7 \pm 5,9$ & $103,65 \pm 16,20$ & \\
\hline & I & 2 & 6,45 & $104,9 \pm 9,4$ & $91,68 \pm 23,17$ & $0,58 \pm 0,27$ \\
\hline & II & 7 & 22,58 & $117,9 \pm 6,6$ & $127,99 \pm 26,36$ & $1,27 \pm 0,47$ \\
\hline & III & 10 & 32,26 & $120,8+7,1$ & $128,20+27,07$ & $1,87 \pm 0,40$ \\
\hline & IV & 5 & 16,13 & $121,4 \pm 5,9$ & $126,09 \pm 24,95$ & $1,24 \pm 0,44$ \\
\hline \multirow{5}{*}{$\begin{array}{l}\text { D. Abu-abu } \\
\text { gelap }\end{array}$} & 0 & 4 & 12,50 & $114,6 \pm 14,0$ & $119,68+47,06$ & \\
\hline & I & 5 & 15,63 & $122,5 \pm 9,4$ & $146,03 \pm 38,16$ & $0,40 \pm 0,25$ \\
\hline & II & 9 & 28,13 & $121,3 \pm 7,7$ & $137,29 \pm 26,53$ & $1,10 \pm 0,32$ \\
\hline & III & 7 & 21,88 & $126,0 \pm 4,4$ & $145,57 \pm 25,95$ & $2,11 \pm 0,99$ \\
\hline & IV & 7 & 21,88 & $120,9 \pm 7,1$ & $155,11 \pm 29,65$ & $1,21 \pm 0,45$ \\
\hline
\end{tabular}

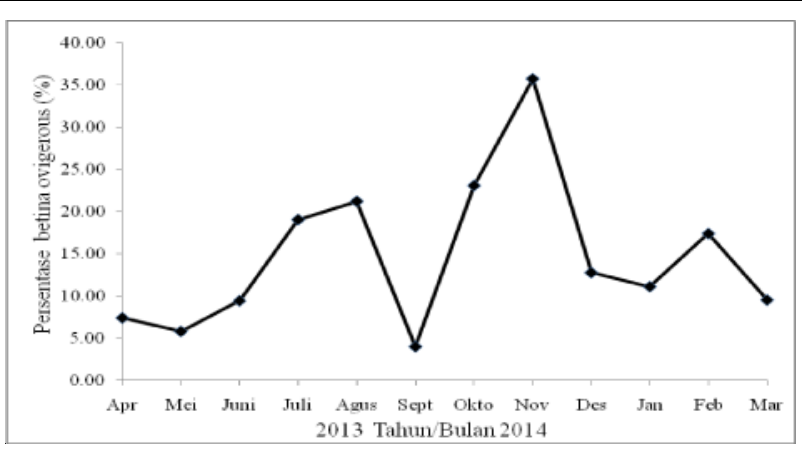

Gambar 3. Persentase tertangkap rajungan betina mengerami telur setiap bulan.

Figure 3. Percentage of ovigerous female blue swimming crab by month. 


\section{BAHASAN}

Hasil penelitian ditemukan berat telur dan indeks masa telur rajungan betina mengerami telur berwarna coklat muda lebih besar dari pada warna kuning dan orange. Indeks masa telur rajungan betina pada penelitian ini lebih besar dari yang ditemukan Sukumaran (1995) dan Josileen (2013). Hubungan berat tubuh dengan berat telur rajungan betina telur sangat nyata, berkorelasi kuat dan positif, hal ini menandakan bahwa semakin berat tubuh rajungan betina mengerami telur, juga berpotensi menghasilkan telur semakin berat.

Fekunditas dan lebar karapas rajungan ditemukan pada penelitian ini masih dalam kisaran fekunditas dan lebar kaparas rajungan betina mengerami telur pada beberapa perairan di dunia, yaitu masing-masing berkisar 431006.656.599 butir dan 32-190 mm (Tabel 5). Fekunditas rajungan tertinggi ditemukan di Teluk Persia dan Laut Oman (Safaie et al., 2013) dan terendah ditemukan di Port Dickson, Malaysia (Ikhwanuddin et al., 2012). Fekunditas rajungan pada penelitian ini lebih tinggi dari pada di pantai Mayangan (Sulistiono et al., 2009) dan pantai Pati (Ernawati, 2013). Berdasarkan fekunditas dan ukuran tubuh rajungan betina (Tabel 5), potensi reproduksi rajungan di Teluk Lasongko tergolong sedang sampai tinggi.

Beberapa hasil penelitian fekunditas rajungan seperti tertera pada Tabel 5 menunjukkan bahwa fekunditas rajungan bervariasi antar lokasi geografi perairan. Beberapa penyebab terjadinya variasi fekunditas rajungan tersebut, karena perbedaan ukuran dan umur rajungan betina, ketersedian makanan, ukuran dan struktur populasi, dan serangan parasit (Shields \& Wood, 1993, Sukumaran 1995, Arshad et al., 2006, Johnson et al., 2010, Ikhwanuddin et al., 2011, Josileen, 2013, Safaie et al., 2013) antar lokasi perairan. Perbedaan suhu air, salinitas dan fotoperiode (Shields \& Wood ,1993, de Lestang et al., 2003, Arshad et al., 2006, Johnson et al., 2010, Ikhwanuddin et al., 2011) juga merupakan menyebab terjadinya variasi fekunditas antar lokasi perairan.

Tabel 5. Fekunditas dan lebar karapas rajungan pada beberapa perairan di dunia (* = panjang karapas)

Table 5. Fecundity and carapace width of blue swimming carb on some waters in the world $(*=$ carapace length)

\begin{tabular}{|c|c|c|c|c|}
\hline No. & $\begin{array}{l}\text { Lokasi/ } \\
\text { Location }\end{array}$ & $\begin{array}{c}\text { Fekunditas/ } \\
\begin{array}{c}\text { Fecundity } \\
\text { (butir) }\end{array} \\
\end{array}$ & $\begin{array}{c}\text { Lebar karapas/ } \\
\text { Carapace width } \\
(\mathrm{mm})\end{array}$ & $\begin{array}{c}\text { Sumber/ } \\
\text { Source }\end{array}$ \\
\hline & Pantai Utara Teluk Persia, Iran & $277.421-1.114 .348$ & $32-173$ & Kamrani et al. (2010) \\
\hline 2. & Pantai Timur Teluk Persia, Iran & $150.496-1.106 .215$ & $80-179$ & Jazayeri et al. (2011) \\
\hline 3. & Pantai Teluk Persia \& Laut Oman & $521.027-6.656 .599$ & $103-155$ & Safaie et al. (2013) \\
\hline 4. & Pantai Karnataka, India Barat & $56.000-1.070 .000$ & $80-180$ & Sukumaran, (1995) \\
\hline & Pantai Mandapam, India Tenggara & $60.000-1.976 .398$ & $100-190$ & Josileen, (2013) \\
\hline & Cockburn Sound, Australia Barat & $78.000-1.000 .000$ & $80-180$ & de Lestang et al. (2003) \\
\hline & Teluk Meroten-Queensland & $103.000-1.880 .000$ & $82-135$ & Shields \& Wood. (1993) \\
\hline 10. & Wallis Lake, Australia Tenggara & $463.000-1.781 .000$ & $38-56^{*}$ & Johnson et al. (2010) \\
\hline 11. & Leyte dan Bohol, Filipina & $420.976-1.312 .238$ & $41-70 *$ & Batoy et al. (1987) \\
\hline 12. & Teluk Khung Krabaen, Thailand & $148.237-1.448 .180$ & $85,8-136,0$ & Kunsook, (2011) \\
\hline 13. & Port Dickson, Malaysia & $148.897-835.401$ & $102,25-140,58$ & Arshad et al. (2006) \\
\hline 14. & Pantai Sematan-Sawarak & $213.333-3.376 .666$ & 144-193 & Ikhwanuddin et al. (2011) \\
\hline 15 . & Pantai Johor, Malaysia & 42.100-183.100 & $97,4-133,2$ & Ikhwanuddin et al. (2012) \\
\hline 16. & Pantai Mayangan, Indonesia & $80.998-1.343 .850$ & $87,0-157,0$ & Sulistiono et al. (2009) \\
\hline 17. & Pantai Pati, Indonesia & $351.210-1.347 .000$ & $92,5-124,4$ & Ernawati, (2013) \\
\hline 18. & Teluk Lasngko, Indonesia & $69.747-2.078 .874$ & $86,6-162,3$ & Penelitian ini \\
\hline
\end{tabular}

Koefisien variasi fekunditas rajungan pada setiap kelas ukuran ditemukan pada penelitian ini berkisar 26,01 $71,49 \%$, dan pada setiap warna telur rajungan betina mengerami telur berkisar 23.98-49.00\%. Variasi fekunditas rajungan pada penelitian ini lebih tinggi dari yang ditemukan pada penelitian sebelumnya, yaitu berkisar 3,54-41,25\% (Sukumaran, 1995, Johnson et al., 2010, Safaie et al., 2013), dan koefisien variasi fekunditas rajungan yang dipelihara di laboratorium 37,30\% (Arshad et al., 2006).
Hubungan fekunditas dengan lebar karapas, berat tubuh dan berat telur ditemukan sangat nyata, berkolerasi kuat dan positif, artinya jika ukuran tubuh dan berat telur rajungan betina meningkat, fekunditas juga meningkat, dan hal ini identik dengan ditemukan pada penelitian sebelumnya (Arshad et al., 2006, Johnson et al., 2010, Ikhwanuddin et al., 2012, Safaie et al., 2013). Untuk memprediksi fekunditas rajungan secara empris dengan persamaan regresi linear lebih tepat digunakan berat telur rajungan betina, karena nilai koefisien determinasi $\left(\mathrm{R}^{2}\right)$ hubungan fekunditas dengan berat telur lebih tinggi dari pada lebar karapas dan berat tubuh rajungan. 
Hasil analisis TKG dari 168 ekor rajungan betina mengerami telur $76 \%$ ditemukan dengan TKG I sampai IV dan $24 \%$ belum berkembang gonadnya, hal ini identik dengan ditemukan di Teluk Moreton-Queensland (Sumpton et al., 1994) dan P. spinimanus betina mengerami telur di Ubatuba, Brazil (Santos \& NegreirosFransozo,1999). Rajungan betina mengerami telur matang gonad ditemukan di Teluk Moreton-Queensland berkisar 5- 29\% (Sumpton et al., 1994), lebih rendah dari yang ditemukan pada penelitian ini. Rajungan betina mengerami telur berwarna coklat dan abu-abu gelap didominasi matang gonad dengan persentase $48,39 \%$ dan $44,37 \%$ sedangkan berwarna kuning dan orange didominasi belum matang gonad masing-masing dengan persentase $63,46 \%$ dan 58,33\% (Tabel 5). Hasil penelitian ini menunjukkan bahwa perkembangan gonad dan embrio rajungan betina mengerami telur bersifat simultan. Perkembangan embrio rajungan diantaranya dapat dilihat dari perubahan warna telur mulai dari warna kuning sampai warna abu-abu gelap (Arshad et al., 2006).

Gonad yang sedang berkembang selama rajungan betina mengerami akan dikeluarkan pada tahap berikutnya dan berpotensi meningkatkan hasil reproduksi rajungan (Sumpton et al., 1994). Rajungan dalam satu musim pemijahan dapat mengeluarkan telur lebih dari satu tahap tergantung pada ukuran tubuhnya (de Lestang et al., 2003; Johnston et al., 2010). Rajungan dengan panjang karapas $<55 \mathrm{~mm}$ hanya satu tahap mengeluarkan telur, dan berukuran $>75 \mathrm{~mm}$ sampai tiga tahap dalam satu musim pemijahan (Johnson et al., 2010), hal ini menunjukkan bahwa potensi reproduksi rajungan betina berukuran besar lebih tinggi dari pada berukuran kecil. Hasil analisis histologi ditemukan gonad rajungan terdiri dari oosit muda dan oosit matang sesaat sebelum terjadi ovaluasi (Dhas et al., 1980 dalam Santos \& Negreiros-Fransozo,1999), ini menandakan rajungan betina mengeluarkan telur lebih dari satu tahap dalam satu musim pemijahan.

Rataan IKG rajungan betina mengerami telur TKG I sampai IV ditemukan pada penelitian ini berkisar 0,402,79 dan relatif sama dengan ditemukan di pantai Cochin, India, yaitu berkisar 0.53-2.25 (Pillay \& Nair, 1971). IKG rajungan semakin besar dengan meningkatnya TKG karena ukuran gonad semakin bertambah besar. IKG rajungan betina mengerami ditemukan pada penelitian ini lebih rendah dari pada IKG rajungan betina belum mengerami telur (data tidak disertakan), dan serupa dengan ditemukan di pantai Cochin, India, berkisar 0,276,85 (Pillay \& Nair,1971). IKG rajungan belum mengerami telur pada beberapa penelitian sebelumnya (Sukumaran, 1995, Kamrani et al., 2010, Kunsook, 2011) lain berkisar 0,54-6,36. IKG dan persentase matang gonad rajungan betina mengerami telur selama penelitian ini ditemukan bervariasi, dan identik dengan dilaporkan Pillay \& Nair (1971) dan Sumpton et al. (1994).

Pemijahan rajungan di Teluk Lasongko berlangsung sepanjang tahun dan puncaknya pada bulan Agustus, November dan Februari (Gambar 3) dilihat dari keberadaan rajungan betina mengerami telur. Puncak musim pemijahan rajungan di Teluk Bone terjadi pada bulan Mei dan Desember (Kembaren et al., 2012) dan di pantai Pati terjadi pada bulan Oktober dan November (Ernawati, 2013). Puncak musim pemijahan rajungan bervariasi antar lokasi geografi perairan, dan diantaranya dipengaruhi oleh variasi suhu tahunan (de Lestang et al., 2003).

\section{KESIMPULAN}

Fekunditas rajungan di Teluk Lasongko berkisar 69.7472.078.874 butir, berkorelasi linear dengan tubuh dan bervariasi terhadap ukuran tubuh dan warna rajungan betina mengerami telur. Rajungan betina mengerami telur warna kuning dan orange didominasi belum matang gonad, sebaliknya warna coklat dan abu-abu gelap didominasi matang gonad, dan ini menunjukkan perkembangan gonad dan embrio berlangsung simultan. Potensi rajungan betina di perairan ini tergolong sedang sampai tinggi dilihat dan fekunditas dan ukuran tubuh serta perkembangan kematangan gonad rajungan betina mengerami telur, dan hal ini menunjukkan bahwa keberlanjutan populasi rajungan di Teluk Lasongko akan terjaga, jika nelayan tidak menangkap rajungan betina mengerami telur .

\section{PERSANTUNAN}

Ucapan terima kasih disampaikan kepada DIKTI dan Universitas Halu Oleo yang telah mendanai sebagian penelitian ini melalui Hibah Disertasi Doktor dari penulis pertama, dan juga kepada La Mpiri, Kaharudin, ST dan Umi Kalsum yang telah membantu sampling rajungan di lapangan dan analisis fekunditas. Kami ucapkan terima kasih kepada Dra. Sri Turni Hartati, M.Si dan Dr. Ir. Krismono, MS atas komentar dan saran berharga untuk perbaikan tulisan ini.

\section{DAFTAR PUSTAKA}

Arshad, A., Efrizal, M. S. Kamarudin \& C. R. Saad. 2006. Study on fecundity, embryology and larval development of blue swimming crab Portunus pelagicus (Linnaeus, 1758) under laboratory conditions. Res.J.Fish.\& Hydrobiol. 1 (1): 35-44.

Batoy, C. B., J. F. Sarmago, B. C. Pilapil. 1987. Breeding season, sexual maturity and fecundity of the blue crab, Portunus pelagicus (L.) in selected coastal waters in 
Leyte and vicinity, Philippines. An.Trop.Res., 9 (3): 157177.

de Lestang, S., N. G. Hall \& I. C. Potter. 2003. Reproductive biology of the blue swimmer crab (Portunus pelagicus, Decapoda: Portunidae) in five bodies of water on the west coast of Australia. Fish. Bull., 101: 745-757.

Ernawati, T. 2013. Dinamika populasi dan pengkajian stok sumberdaya rajungan (Portunus pelagicus) di perairan Kabupaten Pati dan sekitarnya. Tesis. Sekolah Pascasarjana, Institut Pertanian Bogor. Bogor. 80 hal.

Hamid, A. 2011. Kondisi kepiting rajungan di Teluk Lasongko Kabupaten Buton Provinsi Sulawesi Tenggara. Jurnal Mitra Bahari. 5(2): 75-86.

Ikhwanuddin, A. P., J. H. Muhamad, M. L. Shabdin \& A. B. Abol-Munafi. 2011. Fecundity of blue swimming crab, Portunus pelagicus Linnaeus, 1758 from Sematan Fishing District, Sarawak coastal water of South China Sea. Borneo J. Resour. Sci. Tech. 1: 46-51.

Ikhwanuddin, M., M. Azra, H. Siti-Aimuni \& A.B. AbolMunafi. 2012. Fecundity, embryonic and ovarian development of blue swimming crab, Portunus pelagicus (Linnaeus, 1758) in coastal water of Johor, Malaysia. Pak.J.Biol.Sci., 15(15): 720-728.

Jazayeri, A., F. Papan, A. Savari \& T. S. Nejad. 2011. Biological investigation of Persian Gulf blue swimmer crab (Portunus pelagicus) in Khuzestan coasts. Journal of American Science, 7(2): 7-13.

Josileen, J. 2013. Fecundity of the blue swimmer crab, Portunus pelagicus (Linnaeus, 1758) (Decapoda, Brachyura, Portunidae) along the coast of Mandapam, Tamil Nadu, India. Crustaceana, 86(1): 48-55.

Johnson, D. D., G. A. Charles \& W. G. Macbeth. 2010. Reproductive biology of Portunus pelagicus in a South-East Australian estuary. Journal of Crustacean Biology, 30 (2): 200-205.

Kamrani, E., A.N. Sabili \& M. Yahyavi. 2010. Stock assessment and reproductive biology of the blue Swimming crab, Portunus pelagicus in Bandar Abbas Coastal Waters, Northern Persian Gulf. Journal of the Persian Gulf(Marine Science), 1 (2): 11-22.
Kembaren, D. D., T. Ernawati \& Suprapto. 2012. Biologi dan parameter populasi rajungan (Portunus pelagicus) di perairan Bone dan sekitarnya. J.lit Perikan.Ind., 18 (4): 273-281.

Kunsook C. 2011. Assessment of stock and movement pattern for sustainable management of blue swimming crab Portunus Pelagicus (Linnaeus, 1758): Case study in Kung Krabaen Bay, Chanthaburi Province, Thailand. $\mathrm{PhD}$ thesis. Department of Biology, Faculty of Science, Chulalongkorn University. Bangkok. 166 pp.

Pillay, K \& N.B. Nair. 1971. The annual reproductive cycles of Uca annulipes, Portunus pelagicus and Metapenaeus affinis (Decapoda : Crustacea) from the South-west coast of India. Mar.Biol., 11: 152-166.

Safaie, M., J. Pazooki, B. Kiabi, M.R. Shokri. 2013. Reproductive biology of blue swimming crab, Portunus segnis (Forskal, 1775) in coastal waters of Persian Gulf and Oman Sea, Iran. Iranian Journal of Fisheries Sciences, 12(2): 430-444.

Santos, S., M. L. Negreiros-Fransozo. 1999. Reproductive cycle of the swimming crab Portunus spinimanus Latreille (Crustacea, Oecapoda, Brachyura) from Ubatuba, Sao Paulo, Brazil. Revta bras. Zool. 16 (4): 1183-1193.

Shields, J. D. \& F. E. I. Wood. 1993. Impact of parasites on the reproduction and fecundity of the blue sand crab Portunus pelagicus from Moreton Bay, Australia. Mar. Ecol.Prog.Ser. 92: 159-170.

Sukumaran, K. K. 1995. Fishery, biology and population dynamics of the marine crabs, Portunus (Portunus) sanguinolentus (Herbst) and Portunus (Portunus) pelagicus (Linnaeus) along the Karnataka Coast. $\mathrm{PhD}$ Thesis. School of Ocean Sciences, Karnataka University. Karwar, India. 403pp.

Sulistiono, T. Nugroho, M. Zahid. 2009. Potensi pengembangan perikanan rajungan Indonesia. Departemen Manajemen Sumberdaya Perairan, Fakultas Perikanan dan Ilmu Kelautan, Institut Pertanian Bogor. Bogor.

Sumpton, W.D., M.A. Potter \& G.S. Smith. 1994. Reproduction and growth of the commercial sand crab, Portunus pelagicus (L.) in Moreton Bay, Queensland. Asian Fisheries Science, 7: 103-113. 